Iranian Journal of Applied Linguistics (IJAL), Vol.18, No.1, March 2015, 29-64

\title{
An Exploratory Study of Teacher Efficacy Doubts in English for Specific Academic Purposes (ESAP) and English for General Purpose (EGP) Instruction
}

\author{
*Mahmood Reza Atai ${ }^{1}$ \\ Professor of Applied Linguistics, \\ Kharazmi University, Tehran, Iran \\ Mohsen Karrabi ${ }^{2}$ \\ Assistant Professor of Applied Linguistics, \\ Amirkabir University of Technology, Tehran, Iran
}

Received 15 August 2014; revised 16 November 2014; accepted 22 December 2014

\begin{abstract}
While teachers' confidence in their abilities is a crucial asset in teachers' professionalism and their identity development, their efficacy doubts are also considered useful. Given the diversity of English Language Teaching (ELT) contexts, this paper probes the dynamic nature of efficacy doubts the teachers face and are expected to resolve in English for General Purposes (EGP) and English for Specific Academic Purposes (ESAP) instruction.
\end{abstract}

$\overline{\text { Email address }}^{\text {: }}$ atai@khu.ac.ir

Email address ${ }^{2}: \underline{\text { m.karrabi@aut.ac.ir }}$

Corresponding Address: No. 43, Mofatteh Street, Department of Foreign

Languages, Faculty of Humanities and Literature, Kharazmi University, Tehran, Iran. 
To this end, based on the existing theoretical frameworks in EGP and ESAP methodology and interviews with 25 university English teachers, two questionnaires were developed and administered to 170 Iranian EGP and ESAP university instructors. The results of factor analysis confirmed five factors underlying ESAP teachers' teaching efficacy doubts and four factors for EGP teachers' teaching efficacy doubts. The results may promise implications for ESAP and EGP teacher education programs; teacher educators may address the common efficacy doubts identified in this study and expose the current in-service and future ESAP and EGP teachers to the typical factors which may potentially hamper their efficacy and help them resolve their efficacy doubts as a means towards professional development.

Keywords: Efficacy doubts; Teacher education; ESAP and EGP instruction; Teacher development and reform

\section{Introduction}

It is generally agreed that teachers' positive attitudes towards themselves and different aspects of their career - ranging from curriculum development and teaching methods to assessment techniques, etc. - are highly important (CochranSmith, 2001). Accordingly, researchers have striven for providing valid and reliable instrumentation for measuring the construct of teacher efficacy. However, the level of specificity at which the instruments could tap the construct of teacher efficacy is still an unresolved challenge and an issue of great concern to researchers. To this end, a number of scales including Webb Scale with three levels of particularity, Teacher Efficacy Scale with two levels of General and Personal efficacy, and Ohio State Teacher Efficacy Scale with three levels of specificity were developed (Tschannen-Moran, Woolfolk Hoy, \& Hoy, 2001).

Despite the advantages of the existing efficacy measures, it is argued that the teachers' confidence in their efficacy is grounded in traditional teaching methods and that the ratings obtained may not be indicative of their successful performance (Wheatley, 2000). Also, teachers' confidence, as identified through these measures, may even hold them back from creating a democratic atmosphere in their classrooms (Wheatley, 2005). 
A democratic educational setting presupposes that teachers should consider themselves as learners and, occasionally, cast doubts on their beliefs and practices according to the ingoing cycle of feedback they receive during their teaching career in their educational context (Dudley-Marling, 1995). More specifically, efficacious teachers are believed to have the capability to bring about changes in the routines of their classrooms following the doubts they may cast on the appropriateness of the approaches they take and methods they adopt and, hence, enhance students' interest in participating in classroom activities (Ross, 1998; Wheatley, 2002). Further, when teachers, as role models for their students, doubt their own abilities and try to remove their deficiencies, the learners may be inclined to doubt their own educational beliefs and make necessary changes in their learning styles and strategies, attitudes towards learning, and/or their personality inclinations, too. This is in line with the reformist view of education (Edwards, 1996), the dynamic concept of personality as an evolving and prone-to-change construct (Hjelle \& Ziegler, 1992) and constructivism (Williams \& Burden, 1997).

Whereas the 'training' approach to teacher education offers pretty exhaustive lists of dos and don'ts, hence, leaving little space for teachers to explore their own maxims (Williams \& Burden, 1997), the constructivist approach to ELT teacher education works for enhancing teachers' professionalism through fostering teachers' self-awareness, supporting their doubting and questioning the status qua and seeking for solutions to the existing problematic areas (Singh \& Richards, 2006).

When ELT becomes more domain-specific and is offered as English for Specific Purposes (ESP) programs, teachers are expected to acquire specific expertise and enjoy rich background both in English language and in the content they are to offer in English (Hyland, 2006). The Globalization trend in higher education and the increase in the number of applicants to international universities as well as the specialization of sciences in terms of different disciplines and majors at universities have resulted in degrees of specificity in English courses as well. That is why English for Academic Purposes (EAP) has adopted two main subcategories, namely, English for General Academic Purposes (EGAP), and English for Specific Academic Purposes (ESAP). While the former addresses the common needs of all 
students in academia irrespective of their majors, the main concern of the latter is foregrounding the discipline-specific requirements that English language education can satisfy (Hyland, 2006). Besides, it is argued that in ESAP programs, like other ELT domains, all related decisions, plannings, methodologies, and course designs should be based on research findings and that teacher education in such programs should receive due attention (Hamp-Lyons, 2011; Harwood \& Petric, 2011).

Therefore, ESAP teachers are expected to be aware of the learners' target language use domain, to know their current needs and capabilities, and to successfully fill the gap in an interactive way so that the learners' questions, voices, and even doubts are attended to (Giroux, 1994). Further, since ESAP instruction is geared to the target domain where the learners are to use language, teachers are to adapt their methodology to efficiently enable the learners to satisfy their communicative needs (Atai \& Fatahi-Majd, 2014). However, at times and in some educational contexts, lack of concordance is observed between how general English teachers and subject teachers, here ESAP instructors, implement the courses, (Chen, 2011) especially in the Iranian context, where the teachers typically design and implement the courses independently, based on their own cognitions and experiences (Atai \& Nazari, 2011; Atai \& Fatahi-Majd, 2014).

Therefore, both EGP and ESAP teachers are assumed to take the role of reflective practitioners trying to continuously reconsider the course objectives, the means and materials available, the teaching methods, and the evaluation process in order to provide the required feedback and modify the courses in line with their learners' needs (Hyland, 2006). As a result, what comes to the foreground is the concept of 'doubt' in teachers' self-efficacy, where various dimensions of ESAP and EGP courses are cast doubt on and carefully examined so that teachers may try appropriate measures to resolve the doubts. Negotiations with learners, making reforms in the curriculum, and developing teachers' professionalism are echoed in the literature as possible merits of casting doubts on self-efficacy. Drawing on the advantages of efficacy doubts, the current study attempted to probe the construct of teachers' efficacy doubts through identifying the relevant factors in EGP and ESAP instruction. To this end, the extent to which the EGP and ESAP teachers doubt their efficacy beliefs was investigated through focusing on different aspects and 
dimensions of teaching profession for resolving of which they may negotiate with others, including their learners.

\section{Review of the Related Literature}

The concept of self-efficacy was put forth by Bandura (1977) within the framework of social cognitive theory wherein self-efficacy is characterized as an individual's perception of his own potentiality and capacity to set the courses of action so that he may obtain the desired outcomes (Tschannen-Moran, Woolfolk Hoy, \& Hoy, 1998). Self efficacy, as a self-regulatory and motivation-driving mechanism, has been investigated in terms of underlying contributory factors and also in relation to such different aspects of teachers' behavior as their job satisfaction, motivation, decision making process, and achievements, to name some (Podell \& Soodak, 1993). Despite the merits enumerated for the construct, it is argued that the confidence such a sense of efficacy builds may hinder teachers from seeking alternatives and creating a democratic atmosphere in their classrooms, where the learners' ideas are also accounted for. Also, it is argued that higher degrees of perceived self-efficacy may prevent teachers' attempts for continuous learning (Wheatly, 2000). Thus, in the subsequent studies, the doubt concept of self-efficacy was foregrounded and efforts were made to probe it in terms of contributing factors.

Teacher efficacy doubts are generally defined as the uncertainty the teachers have about a certain area of activity or interest wherein they are not sure whether or not they have enough capability to handle the situation or tackle the problems with regard to such issues as class managements, teaching methods, or selecting appropriate materials for the class (Wheatly, 2005). In spite of the disadvantages considered for efficacy doubts, it is argued that doubts can help teachers monitor their performance and that such a desirable type of uncertainty is regarded as a trait which is conducive to teachers' development and their taking innovative approaches to teaching as a problem-finding and problem-solving process (Wheatly, 2002).

Teachers' efficacy doubts, despite being problematic at times, are beneficial when more specific teacher efficacy beliefs, rather than the global aspects, are under focus. Thus, the construct of teachers' efficacy doubts are investigated to 
cover everything from mild uncertainty to profound doubts (Wheatly, 2005). As far as ELT is concerned, teaching English for General Purposes (EGP) encompasses the teaching of grammatical points, common vocabulary items, highly frequent expressions, standard pronunciation, and the skills a learner should acquire to complete a language learning task (Hyland, 2006). However, English for Specific Purposes (ESP) refers to specialized English education where developing the communicative uses of English in a specialized field of science, work, or technology are of great importance as knowing general vocabulary items may not suffice to complete a task on a professional subject (ibid.). Further, the current field work research and direct observation of the way ESAP courses are 'incoherently' implemented at universities (Atai, 2002), the negotiation with curriculum developers, syllabus designers, teacher educators, and practitioners all necessitate doubting, questioning, and revising each step so that the final goal of education, i.e. satisfying the learners' needs, could be optimally achieved (Freire, 2005). As the main beneficiaries, learners' ideas are to be accounted for when teachers try to resolve their doubts and while they make attempts to take more unanimous approaches towards offering EAP courses.

\section{ESAP: Gearing programs to specific academic contexts}

Although some scholars do not make a distinction between ESAP and EGAP methodology (Hyland, 2006), it is argued that the ESAP methodology is highly specialized and calls for very close collaboration between language and content experts (Dudley-Evans \& Johns, 1998). An ESAP teacher is expected to be aware of the learners' target language use domain; uncover their present needs and capabilities; and fill in the gap through sustained interaction and cooperation with the stakeholders including students and content teachers. Obviously, learners' voices should be incorporated in all phases of curriculum planning and implementation including methodological decisions and practices (Giroux, 1994) so that the resultant teaching/learning problems and doubts could be collectively resolved.

Hence, in ESAP education, both teachers and learners are expected to reflect on course objectives, the means and materials available, the teaching methods and the evaluation processes, and work collaboratively in order to gear the instruction to 
the learners' needs and course objectives. However, what seems to be a controversial issue in ESAP contexts, including the Iranian situation, is the required qualifications of the practitioners who teach these courses either at content departments or language departments (Atai, 2002). The teachers in these two camps have quite distinct background education and significantly different conceptions of the nature of ESAP education, course objectives, teaching methodologies, as well as assessment techniques (Atai \& Fatahi-Majd, 2014).

Many studies have been conducted on teachers' beliefs about their sense of self efficacy - e.g. pre-service teachers' professional efficacy beliefs (Woolfolk Hoy \& Spero, 2005), teachers' sense of self-efficacy and their sense of modesty (Cheung, 2008), incorporating critical pedagogy into teacher efficacy measures (Izadinia, 2011). However, despite the plethora of research on different aspects of ELT teachers' self-efficacy, the literature is still scanty with regard to the concept of teachers' efficacy doubts especially in ESAP and EGP education. Such doubts are argued to contribute to a democratic context (Wheatly, 2002) in which the ESAP and EGP teachers may be given the chance to revisit their professional performance and take the required actions to enhance their practice through the feedback they receive from other participants and stakeholders.

\section{The Present Study}

"Doubt is the necessary tool of knowledge ..." (Wheatley, 2002, p.1) and the present research aims to explore the factors which contribute to ESAP and EGP teachers' teaching-efficacy doubts. Such doubts, as a tool of knowledge, would drive teachers to revisit their teaching efficacy beliefs and encourage teacher educators to address the common efficacy doubts when they offer pre- or in-service training courses for ESAP and EGP teachers. The current research sought answers to the following questions:

1. What aspects of their teaching efficacy do ESAP teachers cast doubt on?

2. What aspects of their teaching efficacy do EGP teachers cast doubt on?

3. With regard to resolving which aspects of their teaching-efficacy doubts do ESAP teachers negotiate with their learners?

4. With regard to resolving which aspects of their teaching-efficacy doubts do EGP teachers negotiate with their learners? 


\begin{abstract}
Method
Participants

A sample of 25 university English language teachers, 13 males and 12 females, who were familiar with the concepts of self-efficacy and teacher education issues and had the experience of offering courses in teacher education as well as teaching EGP and ESAP in their profiles participated in the questionnaire development phase of this study. The original participants who participated in the study for probing the construct of teacher efficacy doubts were 170 ESAP and EGP university teachers ( 95 males and 75 females).
\end{abstract}

\title{
Instrumentation
}

Three instruments were utilized in this study:

\section{Open-ended interview:}

Thirty six open-ended questions were designed based on the principles of teacher efficacy, teaching-efficacy doubts, and the specific features of ESAP and EGP instruction. Also, the 24 items of the long version of the Teachers' Sense of Efficacy Scale, developed by Tschannen-Moran, Woolfolk Hoy, and Hoy (2001), were closely scrutinized and the three domains of efficacy for "instructional strategies", "classroom management", and "student engagement" were adopted for the purpose of developing the interview scheme in this study. To incorporate the 'doubt' concept of teaching efficacy, the key issues of the potential benefits of teacher efficacy doubts were extracted from the literature provided by Wheatley (2002). Teachers' "applied methodology", "material selection", "assessing learners", "technology use", "cooperation and collaboration with learners and other teachers", and "assigning pair and group work to learners" are among the issues raised by Wheatley (2002).

To account for ESAP and EGP factors, based on the ideas borrowed from Dudley-Evan and John (1998), Hutchinson and Waters (1987), Hyland (2006), and Robinson (1991), such issues as "the importance of needs analysis in the course", "the necessity of being aware of genres", "the significance of discourse communities", "the role of teachers' prestige", and "content vs. language knowledge" were incorporated in the interview questions. 
The close-ended ESAP and EGP teachers' efficacy doubt questionnaires:

In order to develop the questionnaire items, the content of the recorded interviews were analyzed conceptually. The major themes derived from the content analysis of the interviews with ESAP and EGP teachers were their doubts about "selecting appropriate teaching methods" and "suitable materials", "taking new roles as the learners' needs vary at different learning stages", "evaluating the learners", "managing the classroom", "making use of technology", "providing the chances for learners' contribution both to the classroom content and method selection", "being attentive to learners' criticisms", and "making rapport with their colleagues" in their own department as well as other related ones.

Finally, those concepts which were put forward by the interviewees and had the frequency of 10 or more were shortlisted. The concepts were written as items enabling the teachers to self-evaluate the extent they cast doubts on their efficacy beliefs. The final version of the questionnaires for ESAP and EGP included 30 and 24 items, respectively, designed based on a five-point Likert scale ranging from never, 1 , to always, 5 .

\section{Analysis of ESAP questionnaire results}

In order to answer the first research question probing the factors underlying ESAP teachers' teaching-efficacy doubts, the corresponding questionnaire developed for the purpose of this study was administered to 170 participants. The Principal Component Analysis with Varimax Rotation and Kaiser Normalization run on the results provided evidence for construct validity of the questionnaire. The results revealed 5 components with factor loadings of higher than 0.300 as depicted in Table 3 below. 
Table 3

Factor Loadings of the Questionnaire Items indicating ESAP Teachers' Efficacy Doubts

\begin{tabular}{|l|c|c|c|c|c|c|}
\hline & \multicolumn{7}{|c}{ Component } \\
\hline Items & $\mathbf{1}$ & $\mathbf{2}$ & $\mathbf{3}$ & $\mathbf{4}$ & $\mathbf{5}$ & $\mathbf{6}$ \\
\hline $\mathbf{0 1}$ & $\mathbf{0 . 7 8 8}$ & 0.081 & 0.137 & 0.038 & 0.028 & 0.181 \\
\hline $\mathbf{0 2}$ & 0.129 & 0.029 & 0.039 & $\mathbf{0 . 7 5 2}$ & 0.096 & 0.020 \\
\hline $\mathbf{0 3}$ & 0.011 & 0.234 & 0.046 & $\mathbf{0 . 6 5 3}$ & 0.019 & 0.210 \\
\hline $\mathbf{0 4}$ & 0.013 & $\mathbf{0 . 6 0 6}$ & 0.042 & 0.165 & 0.026 & 0.017 \\
\hline $\mathbf{0 5}$ & 0.047 & 0.014 & $\mathbf{0 . 8 2 3}$ & 0.053 & 0.039 & 0.268 \\
\hline $\mathbf{0 6}$ & 0.100 & 0.074 & $\mathbf{0 . 6 3 2}$ & 0.048 & 0.124 & 0.081 \\
\hline $\mathbf{0 7}$ & 0.011 & 0.126 & 0.015 & $\mathbf{0 . 4 2 5}$ & 0.026 & 0.141 \\
\hline $\mathbf{0 8}$ & 0.181 & $\mathbf{0 . 5 6 7}$ & 0.032 & 0.037 & 0.099 & 0.213 \\
\hline $\mathbf{0 9}$ & 0.029 & $\mathbf{0 . 7 4 8}$ & 0.052 & 0.185 & 0.070 & 0.124 \\
\hline $\mathbf{1 0}$ & 0.016 & 0.034 & 0.106 & 0.053 & $\mathbf{0 . 6 7 5}$ & 0.060 \\
\hline $\mathbf{1 1}$ & 0.049 & 0.195 & 0.031 & 0.104 & $\mathbf{0 . 6 0 9}$ & 0.126 \\
\hline $\mathbf{1 2}$ & 0.117 & 0.033 & 0.059 & 0.070 & $\mathbf{0 . 7 5 8}$ & 0.042 \\
\hline $\mathbf{1 3}$ & 0.145 & 0.014 & 0.055 & $\mathbf{0 . 6 9 3}$ & 0.190 & 0.064 \\
\hline $\mathbf{1 4}$ & $\mathbf{0 . 7 1 6}$ & 0.032 & 0.044 & 0.044 & 0.252 & 0.066 \\
\hline $\mathbf{1 5}$ & 0.022 & 0.122 & 0.282 & 0.036 & $\mathbf{0 . 6 3 3}$ & 0.125 \\
\hline $\mathbf{1 6}$ & 0.027 & 0.053 & $\mathbf{0 . 6 4 5}$ & 0.157 & 0.191 & 0.031 \\
\hline $\mathbf{1 7}$ & 0.044 & $\mathbf{0 . 5 7 9}$ & 0.151 & 0.046 & 0.012 & 0.132 \\
\hline $\mathbf{1 8}$ & $\mathbf{0 . 7 9 0}$ & 0.052 & 0.016 & 0.100 & 0.079 & 0.097 \\
\hline $\mathbf{1 9}$ & $\mathbf{0 . 6 4 9}$ & 0.227 & 0.036 & 0.086 & 0.091 & 0.161 \\
\hline $\mathbf{2 0}$ & 0.054 & $\mathbf{0 . 5 8 3}$ & 0.094 & 0.110 & 0.056 & 0.019 \\
\hline $\mathbf{2 1}$ & $\mathbf{0 . 4 1 9}$ & 0.028 & 0.226 & 0.054 & 0.250 & 0.077 \\
\hline $\mathbf{2 2}$ & 0.023 & 0.079 & $\mathbf{0 . 4 2 2}$ & 0.198 & 0.029 & 0.212 \\
\hline $\mathbf{2 3}$ & $\mathbf{0 . 5 7 1}$ & 0.222 & 0.031 & 0.076 & 0.018 & 0.244 \\
\hline $\mathbf{2 4}$ & 0.030 & 0.136 & $\mathbf{0 . 5 8 4}$ & 0.012 & 0.071 & 0.090 \\
\hline $\mathbf{2 5}$ & 0.192 & 0.119 & 0.071 & 0.028 & $\mathbf{0 . 4 9 8}$ & 0.233 \\
\hline $\mathbf{2 6}$ & $\mathbf{0 . 8 5 2}$ & 0.029 & 0.039 & 0.129 & 0.096 & 0.020 \\
\hline $\mathbf{2 7}$ & 0.011 & 0.046 & $\mathbf{0 . 7 5 0}$ & 0.234 & 0.019 & 0.066 \\
\hline $\mathbf{2 8}$ & 0.125 & 0.016 & $\mathbf{0 . 7 9 8}$ & 0.038 & 0.011 & 0.113 \\
\hline $\mathbf{2 9}$ & $\mathbf{0 . 8 3 3}$ & 0.047 & 0.268 & 0.014 & 0.023 & 0.039 \\
\hline $\mathbf{3 0}$ & 0.025 & 0.215 & $\mathbf{0 . 6 9 8}$ & 0.023 & 0.048 & 0.115 \\
\hline & & & & & & \\
\hline
\end{tabular}


As Table 3 indicates, the majority of the items loaded on factors 1 to 5: the first factor included 8 items; the second factor comprised 5 items; the third factor subsumed 8 items; factor four represented 4 items; and the fifth factor indicated loadings of 5 items. However, no significant factor loading emerged for factor six. The extracted factors were labeled as: 1) ESAP teachers' general sense of teachingefficacy doubts; 2) ESAP teachers' efficacy doubts on their ability to account for learners' feedback; 3) ESAP teachers' efficacy doubts on their ability to make necessary changes in the curriculum; 4) ESAP teachers' efficacy doubts on their ability to meet the students' needs in the classroom; and 5) ESAP teachers' efficacy doubts on their ability to involve learners in educational activities.

In order to estimate the reliability indices of the five extracted factors, Cronbach Alpha Coefficient was utilized. The results indicated a range of reliability indices for the five factors between 0.50 and 0.74 .

$\checkmark$ ESAP teachers' general sense of teaching-efficacy doubts $\rightarrow \alpha=0.740$

$\checkmark$ ESAP teachers' efficacy doubt on their ability to account for learners' ideas $\rightarrow \alpha=0.508$

$\checkmark$ ESAP teachers' efficacy doubt on their ability to make necessary changes $\rightarrow \alpha$ $=0.696$

$\checkmark$ ESAP teachers' efficacy doubt on their ability to meet the class needs $\rightarrow \alpha=$ 0.512

$\checkmark$ ESAP teachers' efficacy doubt on their ability to involve learners in educational activities

$\rightarrow \alpha=0.556$

Regarding the reliability indices, it should be noted that human behavior and perceptions may change both intra- and inter-contextually (Hjelle \& Ziegler, 1992). Therefore, inconsistencies in respondents' perceptions resulting in relatively low reliability indices for some factors can be attributed to some latent sub-constructs interfering with the major extracted factor (Cortina, 1993; Zimmerman, Zumbo, \& Lalonde, 1993; Helms, Henze, Sass, \& Mifsud, 2006). Future research may probe and validate the underlying construct in various educational contexts. 


\section{Areas of ESAP Teachers' Doubts}

In order to investigate the aspects of teaching efficacy which ESAP teachers cast doubts on, the ESAP teachers' responses to each of the items were tabulated and categorized and the corresponding percentages for the participants' responses for each item of the questionnaire were calculated. It should be mentioned that the areas of doubts were reported based on the aspects that 50 percent of the ESAP teachers responded that they 'usually' or 'always' doubted. The results are depicted in Table 4 below.

Table 4

Frequency and Percentage of ESAP Teachers' Areas of Doubt

\begin{tabular}{|c|c|c|c|c|c|}
\hline & Never & Seldom & Often & Usually & Always \\
\hline \multicolumn{6}{|l|}{$\begin{array}{l}\text { Factor 1: general sense of teaching } \\
\text { efficacy doubts }\end{array}$} \\
\hline $\begin{array}{l}\text { 1. How often do you cast doubt on } \\
\text { the effectiveness of your teaching } \\
\text { career? }\end{array}$ & $\begin{array}{c}23 \\
(13.5 \%)\end{array}$ & $\begin{array}{c}21 \\
(12 \%)\end{array}$ & $\begin{array}{c}33 \\
(19.5 \%)\end{array}$ & $\begin{array}{c}68 \\
(40 \%)\end{array}$ & $\begin{array}{c}25 \\
(15 \%)\end{array}$ \\
\hline $\begin{array}{l}\text { 14. How often do you question your } \\
\text { general language proficiency and try } \\
\text { to improve it? }\end{array}$ & $\begin{array}{c}20 \\
(12 \%)\end{array}$ & $\begin{array}{c}31 \\
(18 \%)\end{array}$ & $\begin{array}{c}35 \\
(20.5 \%)\end{array}$ & $\begin{array}{c}23 \\
(13.5 \%)\end{array}$ & $\begin{array}{c}61 \\
(36 \%)\end{array}$ \\
\hline $\begin{array}{l}\text { 18. How often do you think the } \\
\text { amount of expertise you have in } \\
\text { ESAP teaching cannot contribute to } \\
\text { your achievements? }\end{array}$ & $\begin{array}{c}35 \\
(20.5 \%)\end{array}$ & $\begin{array}{c}43 \\
(25 \%)\end{array}$ & $\begin{array}{c}18 \\
(10.5 \%)\end{array}$ & $\begin{array}{c}38 \\
(22 \%)\end{array}$ & $\begin{array}{c}36 \\
(22 \%)\end{array}$ \\
\hline $\begin{array}{l}\text { 19. How often do you think the way } \\
\text { you run an ESAP class is dependent } \\
\text { upon your mentality of an EGP class } \\
\text { hence may not be to the learners' use } \\
\text { and interest? }\end{array}$ & $\begin{array}{c}17 \\
(10 \%)\end{array}$ & $\begin{array}{c}23 \\
(13.5 \%)\end{array}$ & $\begin{array}{c}19 \\
(11 \%)\end{array}$ & $\begin{array}{c}71 \\
(42 \%)\end{array}$ & $\begin{array}{c}40 \\
(23.5 \%)\end{array}$ \\
\hline $\begin{array}{l}\text { 21. How often do you cast doubt on } \\
\text { your performance in different ESAP } \\
\text { classes of the same subject matter } \\
\text { and level? }\end{array}$ & $\begin{array}{c}13 \\
(8 \%)\end{array}$ & $\begin{array}{c}18 \\
(10.5 \%)\end{array}$ & $\begin{array}{c}52 \\
(30.5 \%)\end{array}$ & $\begin{array}{c}44 \\
(26 \%)\end{array}$ & $\begin{array}{c}43 \\
(25 \%)\end{array}$ \\
\hline
\end{tabular}




\begin{tabular}{|c|c|c|c|c|c|}
\hline $\begin{array}{l}23 . \text { How often do you doubt your } \\
\text { ability in utilizing the new } \\
\text { technology (computer, internet) } \\
\text { provided for your class? }\end{array}$ & $\begin{array}{c}8 \\
(5 \%)\end{array}$ & $\begin{array}{c}9 \\
(5 \%)\end{array}$ & $\begin{array}{c}25 \\
(15 \%)\end{array}$ & $\begin{array}{c}54 \\
(32 \%)\end{array}$ & $\begin{array}{c}74 \\
(43 \%)\end{array}$ \\
\hline $\begin{array}{l}\text { 26. How often do you revisit your } \\
\text { flexibility to the criticisms made by } \\
\text { your learners about different aspects } \\
\text { of your teaching career? }\end{array}$ & $\begin{array}{c}12 \\
(7 \%)\end{array}$ & $\begin{array}{c}29 \\
(17 \%)\end{array}$ & $\begin{array}{c}59 \\
(35 \%)\end{array}$ & $\begin{array}{c}52 \\
(30.5 \%)\end{array}$ & $\begin{array}{c}18 \\
(10.5 \%)\end{array}$ \\
\hline $\begin{array}{l}\text { 29. How often do you doubt your } \\
\text { ability and expertise to question the } \\
\text { ESAP curriculum and materials } \\
\text { imposed by the system? }\end{array}$ & $\begin{array}{c}20 \\
(12 \%)\end{array}$ & $\begin{array}{c}14 \\
(8 \%)\end{array}$ & $\begin{array}{c}36 \\
(21 \%)\end{array}$ & $\begin{array}{c}59 \\
(35 \%)\end{array}$ & $\begin{array}{c}41 \\
(24 \%)\end{array}$ \\
\hline $\begin{array}{l}\text { Factor 2: efficacy doubts on the } \\
\text { ability to account for learners } \\
\text { feedback }\end{array}$ & & & & & \\
\hline $\begin{array}{l}\text { 4. How often do you doubt your } \\
\text { capability in applying various } \\
\text { methods to better satisfy the learners' } \\
\text { expectations? }\end{array}$ & $\begin{array}{c}16 \\
(9 \%)\end{array}$ & $\begin{array}{c}21 \\
(13 \%)\end{array}$ & $\begin{array}{c}65 \\
(38 \%)\end{array}$ & $\begin{array}{c}33 \\
(19.5 \%)\end{array}$ & $\begin{array}{c}35 \\
(20.5 \%)\end{array}$ \\
\hline $\begin{array}{l}\text { 8. How often do you encourage your } \\
\text { learners to comment on the way you } \\
\text { evaluate them? }\end{array}$ & $\begin{array}{c}32 \\
(19 \%)\end{array}$ & $\begin{array}{c}36 \\
(21 \%)\end{array}$ & $\begin{array}{c}39 \\
(23 \%)\end{array}$ & $\begin{array}{c}41 \\
(24 \%)\end{array}$ & $\begin{array}{c}22 \\
(13 \%)\end{array}$ \\
\hline $\begin{array}{l}\text { 9. How often do you encourage your } \\
\text { learners to contribute to course } \\
\text { materials? }\end{array}$ & $\begin{array}{c}20 \\
(12 \%)\end{array}$ & $\begin{array}{c}24 \\
(14 \%)\end{array}$ & $\begin{array}{c}40 \\
(23.5 \%)\end{array}$ & $\begin{array}{c}55 \\
(32 \%)\end{array}$ & $\begin{array}{c}31 \\
(18.5 \%)\end{array}$ \\
\hline $\begin{array}{l}\text { 17. How often do you doubt your } \\
\text { ability to enhance your professional } \\
\text { prestige as an ESAP teacher } \\
\text { comparing to that of a content } \\
\text { knowledge teacher in the eyes of the } \\
\text { learners? }\end{array}$ & $\begin{array}{c}7 \\
(4 \%)\end{array}$ & $\begin{array}{c}13 \\
(8 \%)\end{array}$ & $\begin{array}{c}52 \\
(30.5 \%)\end{array}$ & $\begin{array}{c}56 \\
(33 \%)\end{array}$ & $\begin{array}{c}42 \\
(24.5 \%)\end{array}$ \\
\hline $\begin{array}{l}20 . \text { How often do you doubt your } \\
\text { ability to encourage all students to be } \\
\text { involved in the class activities? }\end{array}$ & $\begin{array}{c}35 \\
(20.5 \%)\end{array}$ & $\begin{array}{c}26 \\
(15.5 \%)\end{array}$ & $\begin{array}{c}42 \\
(24.5 \%)\end{array}$ & $\begin{array}{c}38 \\
(22.5 \%)\end{array}$ & $\begin{array}{c}29 \\
(17 \%)\end{array}$ \\
\hline
\end{tabular}




\begin{tabular}{|c|c|c|c|c|c|}
\hline $\begin{array}{l}\text { Factor3: efficacy doubt on the } \\
\text { ability to make necessary changes in } \\
\text { the curriculum }\end{array}$ & & & & & \\
\hline $\begin{array}{l}\text { 5. How often do you think the way } \\
\text { you freely choose to assess and } \\
\text { evaluate your learners does not } \\
\text { represent their real abilities? }\end{array}$ & $\begin{array}{c}26 \\
(15.5 \%)\end{array}$ & $\begin{array}{c}30 \\
(18 \%)\end{array}$ & $\begin{array}{c}43 \\
(25.5 \%)\end{array}$ & $\begin{array}{c}30 \\
(18 \%)\end{array}$ & $\begin{array}{c}41 \\
(24 \%)\end{array}$ \\
\hline $\begin{array}{l}\text { 6. How often do you think the } \\
\text { amount of technical content } \\
\text { knowledge you have about the course } \\
\text { materials needs upgrading? }\end{array}$ & $\begin{array}{c}9 \\
(5.5 \%)\end{array}$ & $\begin{array}{c}14 \\
(8.5 \%)\end{array}$ & $\begin{array}{c}22 \\
(13 \%)\end{array}$ & $\begin{array}{c}92 \\
(54 \%)\end{array}$ & $\begin{array}{c}33 \\
(19 \%)\end{array}$ \\
\hline $\begin{array}{l}\text { 16. How often do you reconsider } \\
\text { your effectiveness in applying } \\
\text { different strategies to correct your } \\
\text { learners' errors? }\end{array}$ & $\begin{array}{c}21 \\
(13 \%)\end{array}$ & $\begin{array}{c}53 \\
(31 \%)\end{array}$ & $\begin{array}{c}41 \\
(24 \%)\end{array}$ & $\begin{array}{c}32 \\
(19 \%)\end{array}$ & $\begin{array}{c}23 \\
(13 \%)\end{array}$ \\
\hline $\begin{array}{l}\text { 22. How often do you doubt your } \\
\text { expertise to decide upon the } \\
\text { preferred curriculum in your class? }\end{array}$ & $\begin{array}{c}34 \\
(20 \%)\end{array}$ & $\begin{array}{c}43 \\
(25 \%)\end{array}$ & $\begin{array}{c}39 \\
(23 \%)\end{array}$ & $\begin{array}{c}25 \\
(15 \%)\end{array}$ & $\begin{array}{c}29 \\
(17 \%)\end{array}$ \\
\hline $\begin{array}{l}\text { 24. How often do cast doubt on your } \\
\text { ability to include oral and writing } \\
\text { skills in your ESAP learners' class } \\
\text { activities and their evaluation } \\
\text { process? }\end{array}$ & $\begin{array}{c}13 \\
(8 \%)\end{array}$ & $\begin{array}{c}16 \\
(9 \%)\end{array}$ & $\begin{array}{c}25 \\
(15 \%)\end{array}$ & $\begin{array}{c}65 \\
(38 \%)\end{array}$ & $\begin{array}{c}51 \\
(30 \%)\end{array}$ \\
\hline $\begin{array}{l}\text { 27. How often do you cast doubt on } \\
\text { your ability to establish a fruitful } \\
\text { interaction with your colleagues at } \\
\text { content departments? }\end{array}$ & $\begin{array}{c}18 \\
(10.5 \%)\end{array}$ & $\begin{array}{c}14 \\
(8.5 \%)\end{array}$ & $\begin{array}{c}59 \\
(35 \%)\end{array}$ & $\begin{array}{c}45 \\
(26 \%)\end{array}$ & $\begin{array}{c}34 \\
(20 \%)\end{array}$ \\
\hline $\begin{array}{l}\text { 28. How often do you cast doubt on } \\
\text { your ability to establish a fruitful } \\
\text { interaction with your colleagues at } \\
\text { ELT department? }\end{array}$ & $\begin{array}{c}29 \\
(17 \%)\end{array}$ & $\begin{array}{c}62 \\
(36 \%)\end{array}$ & $\begin{array}{c}35 \\
(20.5 \%)\end{array}$ & $\begin{array}{c}25 \\
(15 \%)\end{array}$ & $\begin{array}{c}19 \\
(11.5 \%)\end{array}$ \\
\hline $\begin{array}{l}\text { 30. How often do you cast doubt on } \\
\text { your ability to apply changes in the } \\
\text { ESAP curriculum and materials } \\
\text { imposed by the system? }\end{array}$ & $\begin{array}{c}12 \\
(7 \%)\end{array}$ & $\begin{array}{c}36 \\
(21 \%)\end{array}$ & $\begin{array}{c}53 \\
(31 \%)\end{array}$ & $\begin{array}{c}48 \\
(28 \%)\end{array}$ & $\begin{array}{c}21 \\
(13 \%)\end{array}$ \\
\hline
\end{tabular}




\begin{tabular}{|c|c|c|c|c|c|}
\hline $\begin{array}{l}\text { Factor 4: efficacy doubts on the } \\
\text { ability to meet students' needs in } \\
\text { classroom }\end{array}$ & & & & & \\
\hline $\begin{array}{l}\text { 2. How often do you question your } \\
\text { ability in providing your class with } \\
\text { appropriate materials which can meet } \\
\text { the learners' present academic needs? }\end{array}$ & $\begin{array}{c}21 \\
(13 \%)\end{array}$ & $\begin{array}{c}31 \\
(18 \%)\end{array}$ & $\begin{array}{c}46 \\
(27 \%)\end{array}$ & $\begin{array}{c}38 \\
(22 \%)\end{array}$ & $\begin{array}{c}34 \\
(20 \%)\end{array}$ \\
\hline $\begin{array}{l}\text { 3. How often do you question your } \\
\text { ability in providing your class with } \\
\text { appropriate materials which can meet } \\
\text { the learners' future occupational / } \\
\text { professional needs? }\end{array}$ & $\begin{array}{c}8 \\
(5 \%)\end{array}$ & $\begin{array}{c}16 \\
(9.5 \%)\end{array}$ & $\begin{array}{c}48 \\
(28 \%)\end{array}$ & $\begin{array}{c}66 \\
(39 \%)\end{array}$ & $\begin{array}{c}32 \\
(18.5 \%)\end{array}$ \\
\hline $\begin{array}{l}\text { 7. How often do you incorporate your } \\
\text { learners' criticism of your teaching } \\
\text { methods in your future methodology? }\end{array}$ & $\begin{array}{c}5 \\
(3.5 \%)\end{array}$ & $\begin{array}{c}24 \\
(14 \%)\end{array}$ & $\begin{array}{c}38 \\
(22 \%)\end{array}$ & $\begin{array}{c}53 \\
(31 \%)\end{array}$ & $\begin{array}{c}50 \\
(29.5 \%)\end{array}$ \\
\hline $\begin{array}{l}\text { 13. How often do you attribute the } \\
\text { general atmosphere of the class } \\
\text { (either boring or interesting) to the } \\
\text { way you manage that class? }\end{array}$ & $\begin{array}{c}14 \\
(8.5 \%)\end{array}$ & $\begin{array}{c}38 \\
(22 \%)\end{array}$ & $\begin{array}{c}60 \\
(35 \%)\end{array}$ & $\begin{array}{c}32 \\
(18.5 \%)\end{array}$ & $\begin{array}{c}26 \\
(16 \%)\end{array}$ \\
\hline \multicolumn{6}{|l|}{$\begin{array}{l}\text { Factor 5: efficacy doubts on the } \\
\text { ability to involve learners in } \\
\text { educational activities }\end{array}$} \\
\hline $\begin{array}{l}\text { 10. How often do you question your } \\
\text { ability to enhance learner autonomy } \\
\text { and independency in your class? }\end{array}$ & $\begin{array}{c}14 \\
(8.5 \%)\end{array}$ & $\begin{array}{c}19 \\
(11.5 \%)\end{array}$ & $\begin{array}{c}36 \\
(21 \%)\end{array}$ & $\begin{array}{c}54 \\
(31.5 \%)\end{array}$ & $\begin{array}{c}47 \\
(27.5 \%)\end{array}$ \\
\hline $\begin{array}{l}\text { 11. How often do you doubt the skills } \\
\text { and strategies you have to encourage } \\
\text { learners to cooperate in the class to } \\
\text { learn ESAP or solve problems? }\end{array}$ & $\begin{array}{c}16 \\
(9.5 \%)\end{array}$ & $\begin{array}{c}17 \\
(10 \%)\end{array}$ & $\begin{array}{c}39 \\
(22.5 \%)\end{array}$ & $\begin{array}{c}68 \\
(40 \%)\end{array}$ & $\begin{array}{c}30 \\
(18 \%)\end{array}$ \\
\hline $\begin{array}{l}\text { 12. How often do you revisit your } \\
\text { capability to get along with learners } \\
\text { of different behavioral /intellectual } \\
\text { features? }\end{array}$ & $\begin{array}{c}10 \\
(5.5 \%)\end{array}$ & $\begin{array}{c}19 \\
(11.5 \%)\end{array}$ & $\begin{array}{c}50 \\
(29.5 \%)\end{array}$ & $\begin{array}{c}43 \\
(25 \%)\end{array}$ & $\begin{array}{c}48 \\
(28.5 \%)\end{array}$ \\
\hline 15. How often do you cast doubt on & 14 & 41 & 58 & 35 & 22 \\
\hline
\end{tabular}




\begin{tabular}{|l|c|c|c|c|c|}
\hline $\begin{array}{l}\text { your ability to seek help from } \\
\text { learners when it comes to a content- } \\
\text { knowledge problem? }\end{array}$ & $(8.5 \%)$ & $(24 \%)$ & $(34 \%)$ & $(20.5 \%)$ & $(13 \%)$ \\
\hline $\begin{array}{l}\text { 25. How often do you doubt your } \\
\text { ability in incorporating the learners' } \\
\text { evaluation of themselves in your final } \\
\text { assessment? }\end{array}$ & $\begin{array}{c}5 \\
(3 \%)\end{array}$ & $\begin{array}{c}12 \\
(7 \%)\end{array}$ & $\begin{array}{c}36 \\
(21 \%)\end{array}$ & $\begin{array}{c}60 \\
(35 \%)\end{array}$ & $\begin{array}{c}57 \\
(33 \%)\end{array}$ \\
\hline
\end{tabular}

The analysis of the ESAP teachers' responses to the questionnaire items revealed that they 'usually' or 'always' cast doubt on their effectiveness in teaching, their teaching methods in different ESAP classrooms while there are similar materials and the students are of the same major, as well as their ability to utilize technology in their classes. They also doubted their efficacy in questioning the curriculum/materials imposed by the education system, enhancing learners' contribution to the course, satisfying the students' future needs, and improving learners' autonomy.

The ESAP teachers also asserted that they 'usually' or 'always' doubted their efficacy to cope with learners who had different personality types or varied in their conduct in the classroom as well as their efficacy in including learners' selfassessment in their final assessment.

\section{ESAP teaching-efficacy doubts and the teachers' negotiating with learners}

The third research question addressed the aspects of teaching efficacy the ESAP teachers cast doubts on and attempted to resolve through negotiations with their learners. To probe this question, we tabulated the ESAP teachers' responses to the corresponding items of the questionnaire and ran the conventional descriptive analysis. It should be mentioned that areas of doubts were decided upon if, for each item, more than 50 percent of the ESAP teachers asserted that they 'usually' or 'always' doubted that specific area . The results are illustrated in Table 5 below. 
Table 5

Frequency and Percentage of ESAP Teachers' Negotiating Doubts with their

Learners

\begin{tabular}{|l|c|c|c|c|c|}
\hline & Never & Seldom & Often & Usually & Always \\
\hline $\begin{array}{l}\text { Items on ESAP Teachers' } \\
\text { Resolving Doubts }\end{array}$ & & & & & \\
\hline $\begin{array}{l}\text { 7. How often do you incorporate } \\
\text { your learners' criticism of your } \\
\text { teaching method in your future } \\
\text { methodology? }\end{array}$ & $\begin{array}{c}5 \\
(3.5 \%)\end{array}$ & $\begin{array}{c}24 \\
(14 \%)\end{array}$ & $\begin{array}{c}38 \\
(22 \%)\end{array}$ & $\begin{array}{c}53 \\
(31 \%)\end{array}$ & $\begin{array}{c}50 \\
(29.5 \%)\end{array}$ \\
\hline $\begin{array}{l}\text { 8. How often do you encourage your } \\
\text { learners to comment on the way you } \\
\text { evaluate them? }\end{array}$ & $\begin{array}{c}32 \\
(19 \%)\end{array}$ & $\begin{array}{c}(21 \%) \\
(26 \%)\end{array}$ & $\begin{array}{c}(24 \%) \\
(23 \%\end{array}$ & $\begin{array}{c}(13 \%) \\
22\end{array}$ \\
\hline $\begin{array}{l}\text { 9. How often do you encourage your } \\
\text { learners to contribute to course } \\
\text { materials? }\end{array}$ & $\begin{array}{c}20 \\
(12 \%)\end{array}$ & $\begin{array}{c}24 \\
(14 \%)\end{array}$ & $\begin{array}{c}(23.5 \%) \\
(32 \%)\end{array}$ & $\begin{array}{c}(18.5 \%) \\
(32 \%\end{array}$ \\
\hline $\begin{array}{l}\text { 15. How often do you cast doubt on } \\
\text { your ability to seek help from } \\
\text { learners when it comes to a content- } \\
\text { knowledge problem? }\end{array}$ & 14 & 41 & 58 & 35 & 22 \\
$(8.5 \%)$ & $(24 \%)$ & $(34 \%)$ & $(20.5 \%)$ & $(13 \%)$ \\
\hline
\end{tabular}




\begin{tabular}{|l|c|c|c|c|c|}
\hline $\begin{array}{l}\text { 25. How often do you doubt your } \\
\text { ability in incorporating the learners' } \\
\text { evaluation of themselves in your } \\
\text { final assessment? }\end{array}$ & $\begin{array}{c}5 \\
(3 \%)\end{array}$ & $\begin{array}{c}12 \\
(7 \%)\end{array}$ & $\begin{array}{c}36 \\
(21 \%)\end{array}$ & $\begin{array}{c}60 \\
(35 \%)\end{array}$ & $\begin{array}{c}57 \\
(33 \%)\end{array}$ \\
\hline $\begin{array}{l}\text { 26. How often do you revisit your } \\
\text { flexibility to the criticisms made by } \\
\text { your learners about different aspects } \\
\text { of your teaching career? }\end{array}$ & $\begin{array}{c}12 \\
(7 \%)\end{array}$ & $\begin{array}{c}29 \\
(17 \%)\end{array}$ & $\begin{array}{c}59 \\
(35 \%)\end{array}$ & $\begin{array}{c}52 \\
(30.5 \%)\end{array}$ & $\begin{array}{c}18.5 \%) \\
(10.5 \%)\end{array}$ \\
\hline
\end{tabular}

As the results show, the ESAP teachers asserted that they 'usually' or 'always' negotiated with their learners in order to resolve their doubts on their "selecting appropriate teaching methods", "encouraging learners to contribute to the course materials", and "motivating and directing them to self-evaluate their performance".

\section{Analysis of EGP questionnaire results}

In order to answer the second research question investigating the factors underlying EGP teachers' teaching-efficacy doubts, the corresponding questionnaire developed for the purpose of this study was administered to 170 participants. Through the Principal Component Analysis with Varimax Rotation and Kaiser Normalization run on the results, the construct validity of the questionnaire was estimated. The results revealed 4 components with factor loadings of higher than 0.300 as depicted in Table 6 below. 
Table 6

Factor Loadings of the Items for EGP Teachers' Efficacy Doubts

\begin{tabular}{|l|c|c|c|c|c|}
\hline & \multicolumn{5}{|c|}{ Component } \\
\hline Items & $\mathbf{1}$ & $\mathbf{2}$ & $\mathbf{3}$ & $\mathbf{4}$ & $\mathbf{5}$ \\
\hline $\mathbf{0 1}$ & $\mathbf{0 . 7 5 9}$ & 0.017 & 0.073 & 0.090 & 0.038 \\
\hline $\mathbf{0 2}$ & 0.016 & 0.010 & $\mathbf{0 . 6 9 2}$ & .100 & 0.078 \\
\hline $\mathbf{0 3}$ & 0.040 & -0.116 & 0.056 & $\mathbf{0 . 7 0 7}$ & -0.180 \\
\hline $\mathbf{0 4}$ & 0.056 & 0.060 & $\mathbf{0 . 7 9 9}$ & 0.107 & 0.069 \\
\hline $\mathbf{0 5}$ & $\mathbf{0 . 6 1 1}$ & 0.106 & 0.065 & 0.021 & -0.141 \\
\hline $\mathbf{0 6}$ & 0.027 & -0.160 & 0.059 & $\mathbf{0 . 6 7 3}$ & 0.079 \\
\hline $\mathbf{0 7}$ & 0.152 & $\mathbf{0 . 7 6 0}$ & 0.023 & 0.075 & 0.028 \\
\hline $\mathbf{0 8}$ & 0.115 & $\mathbf{0 . 5 0 5}$ & 0.075 & 0.090 & 0.083 \\
\hline $\mathbf{0 9}$ & $\mathbf{0 . 7 4 9}$ & 0.011 & 0.115 & -0.145 & 0.094 \\
\hline $\mathbf{1 0}$ & $\mathbf{0 . 7 1 7}$ & 0.024 & -0.296 & 0.089 & 0.155 \\
\hline $\mathbf{1 1}$ & 0.029 & -0.126 & $\mathbf{0 . 6 3 4}$ & -0.120 & 0.057 \\
\hline $\mathbf{1 2}$ & 0.011 & 0.052 & 0.060 & $\mathbf{0 . 7 5 6}$ & 0.127 \\
\hline $\mathbf{1 3}$ & $\mathbf{0 . 7 3 9}$ & 0.070 & 0.060 & 0.129 & 0.104 \\
\hline $\mathbf{1 4}$ & 0.040 & 0.039 & $\mathbf{0 . 8 1 0}$ & 0.025 & 0.033 \\
\hline $\mathbf{1 5}$ & 0.012 & $\mathbf{0 . 6 7 4}$ & 0.091 & 0.178 & 0.078 \\
\hline $\mathbf{1 6}$ & 0.243 & $\mathbf{0 . 6 4 9}$ & 0.029 & 0.035 & 0.041 \\
\hline $\mathbf{1 7}$ & $\mathbf{0 . 5 8 0}$ & 0.012 & 0.173 & 0.111 & 0.069 \\
\hline $\mathbf{1 8}$ & 0.019 & 0.065 & 0.046 & $\mathbf{0 . 8 8 3}$ & 0.109 \\
\hline $\mathbf{1 9}$ & 0.214 & 0.014 & $\mathbf{0 . 6 6 8}$ & 0.081 & 0.022 \\
\hline $\mathbf{2 0}$ & 0.036 & 0.065 & 0.033 & $\mathbf{0 . 5 4 8}$ & 0.178 \\
\hline $\mathbf{2 1}$ & 0.258 & $\mathbf{0 . 5 8 9}$ & 0.134 & 0.026 & 0.161 \\
\hline $\mathbf{2 2}$ & $\mathbf{0 . 6 0 8}$ & 0.013 & 0.139 & 0.015 & 0.060 \\
\hline $\mathbf{2 3}$ & 0.025 & 0.114 & $\mathbf{0 . 5 5 4}$ & 0.187 & 0.076 \\
\hline $\mathbf{2 4}$ & $\mathbf{0 . 6 6 3}$ & 0.098 & 0.047 & 0.175 & 0.110 \\
\hline & & & & & \\
\hline
\end{tabular}


As Table 6 indicates, the majority of the items loaded on factors 1 to 4: the first factor included 8 items; the second factor comprised 5 items; the third factor represented 6 items; and factor four consisted of 5 items. However, no significant factor loading emerged for factor five. The extracted factors were labeled as: 1) EGP teachers' general sense of teaching-efficacy doubts; 2) EGP teachers' efficacy doubts on their ability to account for learners' contribution to the course; 3) EGP teachers' efficacy doubts on their ability to take different responsibilities and roles; and 4) EGP teachers' efficacy doubts on their ability to make changes in their teaching methods and approaches. The operated factor analysis served as an exploratory one since the factors contributing to such a construct had not been investigated and extracted earlier. Thus, the new questionnaire with 4 discrete categories and satisfactory and meaningful loading of items on the corresponding factors, attested to the theory underlying the construct of EGP teaching efficacy doubts; hence, it is claimed to enjoy construct validity.

To estimate the reliability indices of the four extracted factors, Cronbach Alpha Coefficient was utilized and a range of reliability indices between 0.48 and 0.76 was estimated.

$\checkmark$ EGP teachers' general sense of teaching-efficacy doubts $\rightarrow \alpha=0.760$

$\checkmark$ EGP teachers' efficacy doubt on their ability to account for learners' contribution to the course $\rightarrow \alpha=0.622$

$\checkmark$ EGP teachers' efficacy doubt on their ability to take different responsibilities and roles $\rightarrow \alpha=0.527$

$\checkmark$ EGP teachers' efficacy doubt on their ability to make change in their teaching method and approaches $\rightarrow \alpha=0.482$

\section{Areas of EGP teachers' doubts}

In order to investigate the aspects of teaching efficacy which EGP teachers cast doubts on, their responses to each of the items were tabulated and categorized. Then, the corresponding percentages for the responses the participants had given to each of the points of the Likert scale for each item of the questionnaire were calculated. It should be mentioned that areas of doubts were decided upon if, for 
each item, more than 50 percent of the EGP teachers asserted that they 'usually' or 'always' doubt that specific area. The results are depicted in Table 7 below.

\section{Table 7}

Frequency and Percentage of EGP teachers' Areas of Doubt

\begin{tabular}{|c|c|c|c|c|c|}
\hline \multirow{2}{*}{$\begin{array}{l}\text { Factor 1: general sense of } \\
\text { teaching efficacy doubts }\end{array}$} & Never & Seldom & Often & Usually & Always \\
\hline & & & & & \\
\hline $\begin{array}{l}\text { 1. How often do you cast doubt on } \\
\text { the effectiveness of your teaching } \\
\text { career? }\end{array}$ & $\begin{array}{c}14 \\
(8 \%)\end{array}$ & $\begin{array}{c}20 \\
(12 \%)\end{array}$ & $\begin{array}{c}36 \\
(21 \%)\end{array}$ & $\begin{array}{c}59 \\
(35 \%)\end{array}$ & $\begin{array}{c}41 \\
(24 \%)\end{array}$ \\
\hline $\begin{array}{l}\text { 5. How often do you cast doubt on } \\
\text { your ability to take other roles in } \\
\text { the class rather than the one who is } \\
\text { just to transfer language knowledge } \\
\text { to the learners? }\end{array}$ & $\begin{array}{c}7 \\
(4 \%)\end{array}$ & $\begin{array}{c}13 \\
(8 \%)\end{array}$ & $\begin{array}{c}52 \\
(30.5 \%)\end{array}$ & $\begin{array}{c}56 \\
(33 \%)\end{array}$ & $\begin{array}{c}42 \\
(24.5 \%)\end{array}$ \\
\hline $\begin{array}{l}\text { 9. How often do you question your } \\
\text { ability to enhance learner autonomy } \\
\text { and independency in your class? }\end{array}$ & $\begin{array}{c}9 \\
(5.5 \%)\end{array}$ & $\begin{array}{c}14 \\
(8.5 \%)\end{array}$ & $\begin{array}{c}22 \\
(13 \%)\end{array}$ & $\begin{array}{c}92 \\
(54 \%)\end{array}$ & $\begin{array}{c}33 \\
(19 \%)\end{array}$ \\
\hline $\begin{array}{l}\text { 10. How often do you doubt the } \\
\text { skills and strategies you have to } \\
\text { encourage learners to cooperate in } \\
\text { the class to learn English language } \\
\text { or solve problems? }\end{array}$ & $\begin{array}{c}21 \\
(13 \%)\end{array}$ & $\begin{array}{c}46 \\
(27 \%)\end{array}$ & $\begin{array}{c}31 \\
(18 \%)\end{array}$ & $\begin{array}{c}38 \\
(22 \%)\end{array}$ & $\begin{array}{c}34 \\
(20 \%)\end{array}$ \\
\hline $\begin{array}{l}\text { 13. How often do you question } \\
\text { your general language proficiency } \\
\text { and try to improve it? }\end{array}$ & $\begin{array}{c}25 \\
(15 \%)\end{array}$ & $\begin{array}{c}13 \\
(8 \%)\end{array}$ & $\begin{array}{c}16 \\
(9 \%)\end{array}$ & $\begin{array}{c}51 \\
(30 \%)\end{array}$ & $\begin{array}{c}65 \\
(38 \%)\end{array}$ \\
\hline $\begin{array}{l}\text { 17. How often do you cast doubt } \\
\text { on your performance in different } \\
\text { English language classes of the } \\
\text { same level? }\end{array}$ & $\begin{array}{c}25 \\
(15 \%)\end{array}$ & $\begin{array}{c}39 \\
(23 \%)\end{array}$ & $\begin{array}{c}43 \\
(25 \%)\end{array}$ & $\begin{array}{c}34 \\
(20 \%)\end{array}$ & $\begin{array}{c}29 \\
(17 \%)\end{array}$ \\
\hline $\begin{array}{l}22 \text {. How often do you revisit your } \\
\text { flexibility to the criticisms made by }\end{array}$ & $\begin{array}{c}24 \\
(14 \%)\end{array}$ & $\begin{array}{c}20 \\
(12 \%)\end{array}$ & $\begin{array}{c}31 \\
(18.5 \%)\end{array}$ & $\begin{array}{c}55 \\
(32 \%)\end{array}$ & $\begin{array}{c}40 \\
(23.5 \%)\end{array}$ \\
\hline
\end{tabular}




\begin{tabular}{|c|c|c|c|c|c|}
\hline \multicolumn{6}{|l|}{$\begin{array}{l}\text { your learners about different } \\
\text { aspects of your teaching career? }\end{array}$} \\
\hline $\begin{array}{l}\text { 24. How often do you cast doubt } \\
\text { on your ability to apply changes in } \\
\text { the curriculum and materials } \\
\text { imposed by the system? }\end{array}$ & $\begin{array}{c}35 \\
(20.5 \%)\end{array}$ & $\begin{array}{c}38 \\
(22.5 \%)\end{array}$ & $\begin{array}{c}42 \\
(24.5 \%)\end{array}$ & $\begin{array}{c}26 \\
(15.5 \%)\end{array}$ & $\begin{array}{c}29 \\
(17 \%)\end{array}$ \\
\hline \multicolumn{6}{|c|}{$\begin{array}{l}\text { Factor 2: efficacy doubts on the ability to account for } \\
\text { learners' contribution to the course }\end{array}$} \\
\hline $\begin{array}{l}\text { 7. How often do you encourage } \\
\text { your learners to comment on the } \\
\text { way you evaluate them? }\end{array}$ & $\begin{array}{c}33 \\
(19.5 \%)\end{array}$ & $\begin{array}{c}16 \\
(9 \%)\end{array}$ & $\begin{array}{c}21 \\
(13 \%)\end{array}$ & $\begin{array}{c}65 \\
(38 \%)\end{array}$ & $\begin{array}{c}35 \\
(20.5 \%)\end{array}$ \\
\hline $\begin{array}{l}\text { 8. How often do you encourage } \\
\text { your learners to contribute to } \\
\text { course materials? }\end{array}$ & $\begin{array}{c}7 \\
(4 \%)\end{array}$ & $\begin{array}{c}13 \\
(8 \%)\end{array}$ & $\begin{array}{c}52 \\
(30.5 \%)\end{array}$ & $\begin{array}{c}56 \\
(33 \%)\end{array}$ & $\begin{array}{c}42 \\
(24.5 \%)\end{array}$ \\
\hline $\begin{array}{l}\text { 15. How often do you doubt your } \\
\text { effectiveness in making learners } \\
\text { involved in the process of error } \\
\text { correction? }\end{array}$ & $\begin{array}{c}26 \\
(15.5 \%)\end{array}$ & $\begin{array}{c}43 \\
(25.5 \%)\end{array}$ & $\begin{array}{c}30 \\
(18 \%)\end{array}$ & $\begin{array}{c}41 \\
(24 \%)\end{array}$ & $\begin{array}{c}30 \\
(18 \%)\end{array}$ \\
\hline $\begin{array}{l}\text { 16. How often do you doubt your } \\
\text { ability to encourage all students to } \\
\text { be involved in the class activities? }\end{array}$ & $\begin{array}{c}25 \\
(15 \%)\end{array}$ & $\begin{array}{c}39 \\
(23 \%)\end{array}$ & $\begin{array}{c}43 \\
(25 \%)\end{array}$ & $\begin{array}{c}34 \\
(20 \%)\end{array}$ & $\begin{array}{c}29 \\
(17 \%)\end{array}$ \\
\hline $\begin{array}{l}21 . \text { How often do you doubt your } \\
\text { ability in incorporating the } \\
\text { learners' evaluation of themselves } \\
\text { in your final assessment? }\end{array}$ & $\begin{array}{c}13 \\
(8 \%)\end{array}$ & $\begin{array}{c}25 \\
(15 \%)\end{array}$ & $\begin{array}{c}16 \\
(9 \%)\end{array}$ & $\begin{array}{c}51 \\
(30 \%)\end{array}$ & $\begin{array}{c}65 \\
(38 \%)\end{array}$ \\
\hline \multicolumn{6}{|c|}{$\begin{array}{l}\text { Factor3: efficacy doubt on the ability to take } \\
\text { different responsibilities \& roles }\end{array}$} \\
\hline $\begin{array}{l}\text { 2. How often do you question your } \\
\text { ability in providing your class with } \\
\text { appropriate materials which can } \\
\text { meet the learners' needs? }\end{array}$ & $\begin{array}{c}14 \\
(8.5 \%)\end{array}$ & $\begin{array}{c}36 \\
(21 \%)\end{array}$ & $\begin{array}{c}19 \\
(11.5 \%)\end{array}$ & $\begin{array}{c}47 \\
(27.5 \%)\end{array}$ & $\begin{array}{c}54 \\
(31.5 \%)\end{array}$ \\
\hline
\end{tabular}




\begin{tabular}{|c|c|c|c|c|c|}
\hline $\begin{array}{l}\text { 4. How often do you think the way } \\
\text { you freely choose to assess and } \\
\text { evaluate your learners does not } \\
\text { represent their real abilities? }\end{array}$ & $\begin{array}{c}39 \\
(22.5 \%)\end{array}$ & $\begin{array}{c}30 \\
(18 \%)\end{array}$ & $\begin{array}{c}16 \\
(9.5 \%)\end{array}$ & $\begin{array}{c}68 \\
(40 \%)\end{array}$ & $\begin{array}{c}17 \\
(10 \%)\end{array}$ \\
\hline $\begin{array}{l}\text { 11. How often do you revisit your } \\
\text { capability to get along with learners } \\
\text { of different behavioral /intellectual } \\
\text { features? }\end{array}$ & $\begin{array}{c}10 \\
(5.5 \%)\end{array}$ & $\begin{array}{c}48 \\
(28.5 \%)\end{array}$ & $\begin{array}{c}50 \\
(29.5 \%)\end{array}$ & $\begin{array}{c}43 \\
(25 \%)\end{array}$ & $\begin{array}{c}19 \\
(11.5 \%)\end{array}$ \\
\hline $\begin{array}{l}\text { 14. How often do you reconsider } \\
\text { your effectiveness in applying } \\
\text { different strategies to correct your } \\
\text { learners' errors? }\end{array}$ & $\begin{array}{c}14 \\
(8.5 \%)\end{array}$ & $\begin{array}{c}41 \\
(24 \%)\end{array}$ & $\begin{array}{c}58 \\
(34 \%)\end{array}$ & $\begin{array}{c}35 \\
(20.5 \%)\end{array}$ & $\begin{array}{c}22 \\
(13 \%)\end{array}$ \\
\hline $\begin{array}{l}\text { 19. How often do you doubt your } \\
\text { ability in utilizing the new } \\
\text { technology (computer, internet) } \\
\text { provided for your class? }\end{array}$ & $\begin{array}{c}12 \\
(7 \%)\end{array}$ & $\begin{array}{c}5 \\
(3 \%)\end{array}$ & $\begin{array}{c}57 \\
(33 \%)\end{array}$ & $\begin{array}{c}36 \\
(21 \%)\end{array}$ & $\begin{array}{c}60 \\
(35 \%)\end{array}$ \\
\hline $\begin{array}{l}\text { 23. How often do you cast doubt on } \\
\text { your ability to establish a fruitful } \\
\text { interaction with your colleagues? }\end{array}$ & $\begin{array}{c}45 \\
(26 \%)\end{array}$ & $\begin{array}{c}34 \\
(20 \%)\end{array}$ & $\begin{array}{c}59 \\
(35 \%)\end{array}$ & $\begin{array}{c}18 \\
(10.5 \%)\end{array}$ & $\begin{array}{c}14 \\
(8.5 \%)\end{array}$ \\
\hline \multicolumn{6}{|c|}{$\begin{array}{l}\text { Factor 4: efficacy doubts on the ability to make change } \\
\text { in teaching method \& approaches }\end{array}$} \\
\hline $\begin{array}{l}\text { 3. How often do you doubt your } \\
\text { capability in applying various } \\
\text { methods to better satisfy the } \\
\text { learners' expectations? }\end{array}$ & $\begin{array}{c}21 \\
(13 \%)\end{array}$ & $\begin{array}{c}46 \\
(27 \%)\end{array}$ & $\begin{array}{c}31 \\
(18 \%)\end{array}$ & $\begin{array}{c}38 \\
(22 \%)\end{array}$ & $\begin{array}{c}34 \\
(20 \%)\end{array}$ \\
\hline $\begin{array}{l}\text { 6. How often do you incorporate } \\
\text { your learners' criticism of your } \\
\text { teaching method in your future } \\
\text { methodology? }\end{array}$ & $\begin{array}{c}16 \\
(9.5 \%)\end{array}$ & $\begin{array}{c}8 \\
(5 \%)\end{array}$ & $\begin{array}{c}32 \\
(18.5 \%)\end{array}$ & $\begin{array}{c}66 \\
(39 \%)\end{array}$ & $\begin{array}{c}48 \\
(28 \%)\end{array}$ \\
\hline $\begin{array}{l}\text { 12. How often do you attribute the } \\
\text { general atmosphere of the class } \\
\text { (either boring or interesting) to the } \\
\text { way you manage that class? }\end{array}$ & $\begin{array}{c}38 \\
(22 \%)\end{array}$ & $\begin{array}{c}5 \\
(3.5 \%)\end{array}$ & $\begin{array}{c}53 \\
(31 \%)\end{array}$ & $\begin{array}{c}24 \\
(14 \%)\end{array}$ & $\begin{array}{c}50 \\
(29.5 \%)\end{array}$ \\
\hline
\end{tabular}




\begin{tabular}{|l|c|c|c|c|c|}
\hline $\begin{array}{l}\text { 18. How often do you doubt your } \\
\text { expertise to decide upon the } \\
\text { preferred curriculum in your class? }\end{array}$ & $\begin{array}{c}34 \\
(20 \%)\end{array}$ & $\begin{array}{c}43 \\
(25 \%)\end{array}$ & $\begin{array}{c}39 \\
(23 \%)\end{array}$ & $\begin{array}{c}25 \\
(15 \%)\end{array}$ & $\begin{array}{c}29 \\
(17 \%)\end{array}$ \\
\hline $\begin{array}{l}\text { 20. How often do you cast doubt on } \\
\text { your ability to include oral and } \\
\text { writing skills in your learners' class } \\
\text { activities and their evaluation } \\
\text { process? }\end{array}$ & $\begin{array}{c}26 \\
(16 \%)\end{array}$ & $\begin{array}{c}14 \\
(8.5 \%)\end{array}$ & $\begin{array}{c}32 \\
(18.5 \%)\end{array}$ & $\begin{array}{c}60 \\
(35 \%)\end{array}$ & $\begin{array}{c}38 \\
(22 \%)\end{array}$ \\
\hline
\end{tabular}

The analysis of the EGP teachers' responses to the items revealed that they 'usually' or 'always' cast doubt on their efficacy "to offer help to the learners with issues other than mere language knowledge or educational ones", "to enhance learners' autonomy", "to encourage learners to raise criticism against their selecting teaching method, assessing method, materials". They also doubted their efficacy in "making use of technology in the classrooms", "including oral and writing skills in their activities when the course lends itself to a reading one", and "encouraging learners to self-assess their performance during the term".

\section{EGP teaching-efficacy doubts and the teachers' negotiating with learners}

The fourth research question of this study addressed the aspects of teaching efficacy doubts for resolving of which the EGP teachers tended to negotiate with their learners. To this end, EGP teachers' responses to the questionnaire items were tabulated and descriptive analysis including frequency counts and percentages were completed.

Again, areas of doubts were decided upon if, for each item, more than 50 percent of the ESAP teachers asserted that they 'usually' or 'always' doubt that specific area. The results are illustrated in Table 8 below. 
Table 8

Frequency and Percentage of EGP Teachers' Negotiating Doubts with their Learners

\begin{tabular}{|c|c|c|c|c|c|}
\hline \multirow{2}{*}{$\begin{array}{l}\text { Items on EGP Teachers' Resolving } \\
\text { Doubts }\end{array}$} & Never & Seldom & Often & Usually & Always \\
\hline & & & & & \\
\hline $\begin{array}{l}\text { 6. How often do you incorporate your } \\
\text { learners' criticism of your teaching } \\
\text { method in your future methodology? }\end{array}$ & $\begin{array}{c}16 \\
(9.5 \%)\end{array}$ & $\begin{array}{c}8 \\
(5 \%)\end{array}$ & $\begin{array}{c}32 \\
(18.5 \%)\end{array}$ & $\begin{array}{c}66 \\
(39 \%)\end{array}$ & $\begin{array}{c}48 \\
(28 \%)\end{array}$ \\
\hline $\begin{array}{l}\text { 7. How often do you encourage your } \\
\text { learners to comment on the way you } \\
\text { evaluate them? }\end{array}$ & $\begin{array}{c}33 \\
(19.5 \%)\end{array}$ & $\begin{array}{c}16 \\
(9 \%)\end{array}$ & $\begin{array}{c}21 \\
(13 \%)\end{array}$ & $\begin{array}{c}65 \\
(38 \%)\end{array}$ & $\begin{array}{c}35 \\
(20.5 \%)\end{array}$ \\
\hline $\begin{array}{l}\text { 8. How often do you encourage your } \\
\text { learners to contribute to course } \\
\text { materials? }\end{array}$ & $\begin{array}{c}7 \\
(4 \%)\end{array}$ & $\begin{array}{c}13 \\
(8 \%)\end{array}$ & $\begin{array}{c}52 \\
(30.5 \%)\end{array}$ & $\begin{array}{c}56 \\
(33 \%)\end{array}$ & $\begin{array}{c}42 \\
(24.5 \%)\end{array}$ \\
\hline $\begin{array}{l}21 . \text { How often do you doubt your } \\
\text { ability in incorporating the learners' } \\
\text { evaluation of themselves in your final } \\
\text { assessment? }\end{array}$ & $\begin{array}{c}13 \\
(8 \%)\end{array}$ & $\begin{array}{c}25 \\
(15 \%)\end{array}$ & $\begin{array}{c}16 \\
(9 \%)\end{array}$ & $\begin{array}{c}51 \\
(30 \%)\end{array}$ & $\begin{array}{c}65 \\
(38 \%)\end{array}$ \\
\hline $\begin{array}{l}\text { 22. How often do you revisit your } \\
\text { flexibility to the criticisms made by } \\
\text { your learners about different aspects } \\
\text { of your teaching career? }\end{array}$ & $\begin{array}{c}24 \\
(14 \%)\end{array}$ & $\begin{array}{c}20 \\
(12 \%)\end{array}$ & $\begin{array}{c}31 \\
(18.5 \%)\end{array}$ & $\begin{array}{c}55 \\
(32 \%)\end{array}$ & $\begin{array}{c}40 \\
(23.5 \%)\end{array}$ \\
\hline
\end{tabular}

As Table 8 illustrates, the EGP teachers asserted that they 'usually' or 'always' negotiated with their learners to resolve their doubts on "the way they evaluate the learners", "incorporating the learners' self-assessment in the final assessment", and "the appropriacy of the materials and the way learners can contribute to them". "Appropriateness of teaching methods" they used in the classroom was the other issue the EGP teachers perceived that they doubted and sought the learners' negotiations to resolve it. 


\section{Discussion}

As Wheatly (2002) argues, self-efficacy should be examined in relation to the context of teaching; hence, efficacy doubts must be context-dependant and should be explored according to the situation and specificity of the pedagogical context. As pointed out earlier under literature review, the construct of self-efficacy has been operationally defined and validated across different contexts and situations. For efficacy doubts, therefore, it is highly important that the construct should be investigated and their underlying factors in certain contexts, here ESAP and EGP, be probed and operationally defined. The results of interviews, questionnaires, and factor analysis revealed the factors underlying the teachers' efficacy doubts in the ELT contexts under study and, also, the aspects of teaching efficacy the ESAP and EGP teachers commonly cast doubts on and negotiate with their learners to resolve them.

The findings of this research confirmed the point that while teachers' positive beliefs and confidence in their abilities are crucial for improving teachers' development and promoting educational reforms, teachers' doubts about their efficacy are equally important. Such doubts provide an optimal atmosphere where interaction between the learners and their teachers regarding various aspects of the classroom - ranging from methodology, syllabus design, and assessment to class dynamics.

\section{ESAP Context}

\section{ESAP teachers' general sense of teaching-efficacy doubts:}

ESAP teachers generally doubted different aspects of their teaching practice when they tried to question and reflect on their effectiveness as teachers in the context. In other words, what they did, i.e. doubting their general performance, is an inherent part of teaching (Lampert, 1999) and they eventually attempted to find solutions for the uncertainties they encountered (McDonald, 1991).

It is argued that ESAP and EGP should be treated differently and teaching grammar for general purposes, knowledge of general vocabulary items, and nativelike pronunciation should not form the core of ESAP activities (Hyland, 2006). ESAP teachers are expected to occasionally doubt their teaching practices in order 
not to let their EGP teaching practice and methodology dominate their ESAP methodology.

Traditionally, it was argued that teachers are incapable of theorizing for their own practices and follow what others theorize (Clarke, 1994). For an ESAP teacher to be able to question the curriculum planned by the officials, he should assume the responsibility of reflection and hypothesizing. To this end, the ESAP teachers should be encouraged to acquire extensive knowledge about the local education system and the relevant teaching/learning theories. Hence, they would be more inclined to develop problem-posing and problem-solving skills. Casting doubts on the curriculum presupposes teachers' creativity and intellectuality.

ESAP teachers' efficacy doubts on their ability to account for learners' feedback:

The main challenge for ESAP teachers is the specificity of the language and how they may promote language learning (Hyland, 2006); therefore, selecting appropriate materials and evaluation procedures is of utmost importance. Teachers may handle specificity in ESAP instruction through seeking for the learners' contribution. The ESAP teachers' teaching efficacy doubts on their ability to incorporate learners' ideas may encourage the learners to take active roles in the classroom.

A recurrent issue in ESAP instruction is the typically low respect paid by the learners to the teachers, as compared with teachers offering content courses. However, the ESAP teachers can attract the attention of their students by considering learners' unique needs via fostering a more democratic and participatory context in which the learners' rights are taken into account (Benesch, 2001).

ESAP teachers' efficacy doubts on their ability to make necessary changes in the curriculum:

The rapid rate of technology and easy access to primary sources of information have raised learners' expectations of their course content and their ESAP teachers' expertise levels. The necessity for improving their content/technical knowledge and their teaching skills and strategies were the aspects of teaching efficacy the ESAP teachers cast doubt on and asserted that constant revision would be required. 
Uncertainty can also foster productive collaboration among the teachers of the same or different departments (Friedman, 1997). To surmount the problems in the curriculum and resolve the related doubts, ESAP teachers may be inclined to collaborate with their colleagues at content department and ELT department in order to enhance their professionalism.

ESAP teachers' efficacy doubts on their ability to meet the students' needs in classroom:

To meet the students' needs in the classroom, the ESAP teachers should determine the nature of the needs, i.e. what learners' present and target situation needs are and what facilities are required in various contexts (Brown, 1995). Needs analysis helps teachers recognize the challenges the learners may face in ESAP educational contexts (Benesch, 2001). In order for ESAP teachers to implement the course in a way that both the present and target needs of the learners could be satisfied, negotiation with the learners and motivating them to actively participate in classroom activities are highly important (Benson \& Voller, 1997). ESAP teachers' ability to offer materials which can satisfy the future needs of the learners is the other aspect of their teaching efficacy that the respondents in our study asserted they cast doubt on.

\section{ESAP teachers' efficacy doubts on their ability to involve learners in educational activities:}

Teachers are the main decision-makers with regard to the use of instructional strategies, the desired classroom management, and the students' involvement and cooperation (Woolfolk \& Hoy, 1990). To make the learners involved in classroom activities, course content could be offered in such a way that even those content areas which are already known to ESAP learners create "disequilibrium" in their minds (Williams \& Burden, 1997). Making the learners cooperate in classroom and with group members of different behavioral / intellectual features as well as solving problems are the aspects of teaching-efficacy the ESAP teachers commonly doubt.

Obviously, doubts are not signs of failure; rather, they give signals to the areas teachers need improvement. To this end, ESAP teachers can negotiate with learners and incorporate their feedback in their future instruction. They can also encourage the learners to contribute to course materials and seek their advice on the most 
appropriate ones. Negotiating with learners on the ways the ESAP teacher can assess them and on the ways they can self-assess their performances can enhance teacher development as well.

Further, with reference to the merits the construct of teachers' efficacy doubts may promise in an educational context, during teacher education programs as well as pre-service and in-service training courses, teacher educators should highlight the importance of teachers' doubting their beliefs regarding teaching methods they select, materials they choose or develop, and evaluation process they opt for. Such doubts are conducive to teachers' reforms and professional development.

It is also argued that the designers of teacher education programs may include some modules in order to expose the candidates to the common efficacy beliefs and efficacy doubts of novice and experienced teachers. Also, the trainees should be reminded that doubting efficacy beliefs are not counterproductive; rather, they pave the way for teacher development and for creating a democratic atmosphere in classrooms where different voices may be heard.

\section{EGP Context}

\section{EGP teachers' general sense of teaching-efficacy doubts:}

Being aware of one's teaching efficacy and constantly revisiting it, EGP teachers can set higher goals both for themselves and for their learners. Goal-setting and goal-achieving were the aspects the EGP teachers in this study usually cast doubt on. To help learners achieve the goals and become independent, EGP teachers are expected to be appropriate models for the learners and may continuously give feedback on their performance.

\section{EGP teachers' efficacy doubts on their ability to account for learners' contribution:}

To guarantee the social relevance of classroom practice to the learners' life (Kumaravadivelu, 2003) and to let them have their own voices in classroom practice (Giroux, 1994), the learners should be allowed to assert their ideas on the assessment and materials selection processes. In doing so, they are encouraged to take active roles in the classroom and to actively contribute to classroom practices. Therefore, EGP teachers' doubts on the issues of assessment and materials selection 
may eventually result in improving the processes of assessment and materials selection.

EGP teachers' efficacy doubts on their ability to take different roles and responsibilities:

While looking for appropriate materials, in addition to those prescribed by the formal curriculum, EGP teachers are either resourceful enough to feed the classroom with various materials which can serve the learners' purposes and needs or they should take the role of partners (Williams \& Burden, 1997) and share material selection with the learners.

It is argued that recalling the past experiences and evaluating them may help a teacher broaden the scope of his pedagogical activities through making up for lacks and reinforcing the merits (Williams \& Burden, 1997). Becoming a reflective teacher involves moving beyond primary concerns with instructional techniques and asking "what", "why", and "how" questions (Bartlett, 1990). The expression "teachers as advisors/counselors" in humanistic psychology (Richards \& Rodgers, 2014) refers to the responsibility the teachers should assume when dealing with learners of diverse behavioral or intellectual parameters.

\section{EGP teachers' efficacy doubts on their ability to make changes in their teaching methods:}

Many teachers go beyond the conventions in their classroom and try creative options (Wheatley, 2002). One source of motivation for EGP teachers to seek changes in their routines is learners' comments on the methods they stick to and the materials they use. Hence, a critical EGP teacher, in addition to transferring language skills and strategies to the learners, can foster their critical thinking along with teaching tasks and may elicit learner feedback. In doing so, the teacher and the learners help one another to co-construct the reality based on their reflections and findings.

Teachers' efficacy doubts are claimed to have numerous benefits for all the participants in educational contexts, from learners and teachers to high ranking policy makers (Wheatley, 2002); thus, when teachers are encouraged to doubt their teaching beliefs and appreciate its importance, they can confer such a positive attitude to doubts to their learners. 


\section{Conclusion}

This study investigated the factors underlying efficacy doubts in ESAP and EGP instruction and discussed the potential benefits of teacher efficacy doubts for educational reform in the corresponding areas. While global doubts are disadvantageous and supposed to be avoided, specific teacher efficacy doubts in certain aspects of ESAP and EGP instruction can be promising for educational reform and improving the courses. ESAP and EGP teachers' doubts on different aspects of their teaching practice can induce disequilibrium and change in their professional routines, may stimulate their reflections on the appropriateness of methods and materials they use, can motivate them to learn and, hence, be responsive to diversity, and can promote productive collaboration among teachers at language departments and content departments.

This study may promise several implications for ESAP and EGP teacher educators as well as researchers. Teacher educators may prepare ESAP teachers to welcome their efficacy doubts and cope with them constructively, i.e. to learn that doubts on their teaching methods and materials are not negative while satisfying students' needs is the main concern. The doubts the ESAP teachers raise, if not handled properly, can be unsettling and disruptive if they have not been trained, in their teacher-education courses, to make the best of their doubts.

In order for ESAP teachers to learn from efficacy doubts, teacher educators may share their own efficacy doubts, both in ESAP and EGP contexts, with teacher trainees and provide them with insights on seeking for ways to resolve them through reflection as well as negotiations with their learners. Finally, ESAP and EGP teachers who doubt their teaching efficacy are more likely to call for the support of their counterparts in other departments. As they strive to resolve their doubts, they may feel more enthusiastic about their career and grow much more commitment to it.

Notes on Contributors:

Mahmood Reza Atai is professor of Applied Linguistics at Kharazmi University, Tehran, Iran. His research interests include ESP, needs analysis, genre analysis, 
and EAP teacher education. His has published extensively on the above themes in international and national journals.

Mohsen Karrabi, as an assistant professor at Amir Kabir University of Technology, Tehran, Iran, is now offering EAP and TESOL courses. He has also supervised and advised MA theses on TESOL themes. His research interests include teacher education, SLA, and EST genre analysis.

\section{References}

Atai, M. R. (2002). ESAP curriculum development in Iran: An incoherent educational experience. Journal of Faculty of Letters and Humanities, 9, 1734.

Atai, M. R., \& Fatahi-Majd, M. (2014). Exploring the practices and cognitions of Iranian ELT instructors and subject teachers in teaching EAP reading comprehension. English for Specific Purposes, 33(1), 27-38.

Atai, M. R., \& Nazari, O. (2011). Exploring reading comprehension needs of Iranian EAP students of health information management (HIM): A triangulated approach. System, 39(1), 30-43.

Bandura, A. (1977). Self-efficacy: Toward a unifying theory of behavioral change. Psychological Review, 84 (2), 191-215.

Bartlett, L. (1990). Teacher development through reflective teaching. In J. C. Richards, \& D. Nunan (Eds.), Second language teacher education, (pp. 202214). New York: Cambridge University Press.

Benesch, S. (2001). Critical English for academic purposes. Mahwah, NJ: Erlbaum. 
Benson, P., \& Voller, P. (1997). Autonomy and independence in language learning. London: Longman.

Brown, J. D. (1995). The Elements of language curriculum: A systematic approach to program development. Boston, Massachusetts: Heinle \& Heinle Publishers.

Clarke, M. A. (1994). The Dysfunctions of the theory/practice discourse. TESOL Quarterly, 28 (1), 9-26.

Chen, Y. (2011). The institutional turn and the crisis of ESP pedagogy in Taiwan. Taiwan International ESP Journal, 3(1), 17-30.

Cheung, H. Y. (2008). The Measurement of teacher efficacy: Hong Kong primary in-service teachers. Journal of Education for Teaching, 32 (4), 435-451.

Cochran-Smith, M. (2001). Reforming teacher education: Competing agendas. Journal of Teacher Education, 52 (4), 263-265.

Cortina, J. M. (1993). What is coefficient alpha? An examination of theory and applications. Journal of Applied Psychology, 78, 96-104.

Donaghue, H. (2003). An instrument to elicit teachers' beliefs and assumptions. ELT Journal, 57 (4), 344-351.

Dudley-Evans, T., \& John, St M. (1998). Developments in English for specific purposes. Cambridge: Cambridge University Press.

Dudley-Marling, C. (1995). Uncertainty and the whole language teacher. Language Arts, 72, (4), 252-257. 
Edwards, T. G. (1996). Implications of a model for conceptualizing change in mathematics teachers' instructional practices. Action in Teacher Education, 18 (2), 19-30.

Freire, P. (2005). Education for critical consciousness (Revised edition). London, UK: Continuum.

Friedman, I. (1997). Making schools safe for uncertainty: Teams, teaching, and school reform. Teachers College Record, 99 (2), 335-370.

Giroux, H. A. (1994). Disturbing pleasures: Learning popular culture. New York: Routledge.

Hjelle, L. A., \& Ziegler, D. J. (1992). Personality theories: Basic assumptions, research, and applications. New York: McGraw-Hill, Inc.

Hamp-Lyons, L. (2011). English for academic purposes. In E. Hinkel (Ed.), Handbook of research in second language teaching and learning (pp. 89105). Hillsdale, NJ: Lawrence Erlbaum Associates.

Harwood, N., \& Petric, B. (2011). English for academic purposes. In J. Simpson (Ed.), The Routledge Handbook of Applied Linguistics (pp. 243-258). London: Routledge.

Helms, J. E., Henze, K. T., Sass, T. L., \& Mifsud, V.A. (2006). Treating Cronbach's reliability coefficients as data in counseling research. The Counseling Psychologist, 34(5), 630-660.

Hyland, K. (2006). English for academic purposes: An advanced resource book. New York: Routledge, Taylor and Francis Group. 
Izadinia, M. (2011). Incorporating the principles of critical pedagogy into a teacher efficacy measure. English Language Teaching, 4 (2), 138-150.

Johns, A. M., \& Dudley-Evans, T. (1991). English for specific purposes: International in scope, specific in purpose. TESOL Quarterly, 25 (2), 297313.

Kumaravadivelu, B. (2003). Beyond methods: Macrostrategies for language teaching. New Haven and London: Yale University Press.

Lampert, M. (1999). Knowing teaching from the inside out: Implications of inquiry in practice for teacher education. Chicago, IL: The National Society for the Study of Education.

McDonald, J. (1991). A messy business: Experience allows teachers to cope with uncertainty, not eliminate it. Teacher Magazine, 3 (3), 54-55.

Podell, D. M., \& Soodak, L. C. (1993). Teacher efficacy and bias in special education referrals. Journal of Educational Research, 86, 247-253.

Richards, J. C., \& Rodgers, T. S. (2014). Approaches and methods in language teaching ( $3^{\text {rd }}$ Edition). Cambridge: Cambridge University Press.

Robinson, P.C. (1991). ESP today: A practitioner's guide. Englewood Cliffs, NJ: Prentice Hall.

Ross, J. A. (1998). The antecedents and consequences of teacher efficacy. Advances in Research on Teaching, 7, 49-73.

SchÖn, D. A. (1983). The reflective practitioner: How professional think in Action. New York: Basic Books. 
Singh, G., \& Richards, J. C. (2006). Teaching and learning in the language teacher education course room: A critical socio-cultural perspective. RELC, 37 (2), 149-175.

Tschannen-Moran, M., Woolfolk Hoy, A., \& Hoy, W. K. (1998). Teacher efficacy: Its meaning and measure. Review of Educational Research, 68 (2), 202-248.

Tschannen-Moran, M., \& Woolfolk Hoy, A. (2001). Teacher efficacy: Capturing an elusive construct. Teaching and Teacher Education, 17 (7), 783-805.

Wheatley, K. F. (2000). Positive teacher efficacy as an obstacle to educational reform. Journal of Research and Development in Education, 34 (1), 14-27.

Wheatley, K. F. (2002). The potential benefits of teacher efficacy doubts for educational reform. Teaching and Teacher Education, 18 (1), 5-22.

Wheatley, K. F. (2005). The case for reconceptualizing teacher efficacy research. Teaching and Teacher Education, 21 (7), 747-766.

Williams, M., \& Burden, R. L. (1997). Psychology for language teachers: A social constructivist approach. $1^{\text {st }}$ Edition. Cambridge: Cambridge University Press.

Woolfolk, A. E., \& Hoy, W. K. (1990). Prospective teachers' sense of efficacy and beliefs about control. Journal of Educational Psychology, 82 (1), 81-91.

Woolfolk Hoy, A., \& Spero, R. B. (2005). Changes in teacher efficacy during the early years of teaching: A comparison of four measures. Teaching and Teacher Education, 21(4), 343-356.

Zimmerman, D. W., Zumbo, B. D., \& Lalonde, C. (1993). Coefficient alpha as an estimate of test reliability under violation of two assumptions. Education and Psychological Measurement, 53, 33-49. 